\title{
The chamomile aromatherapy reduce the scale of nausea
}

\author{
Ima Nurcahyanti Putri, Rizky Amelia, Sri Rahayu
}

Department of Midwifery, Health Polytechnic of Semarang, Indonesia

\begin{tabular}{l} 
Article Info \\
\hline Article history: \\
Received Jul 1, 2019 \\
Revised Aug 12, 2019 \\
Accepted Aug 25, 2019 \\
\hline
\end{tabular}

\section{Keywords:}

Aromatherapy chamomile Cervical cancer

Nausea

Vomitting

\begin{abstract}
The incidence of cervical cancer in the world is 17 per 100,000 women, while the mortality rate ranges from 8.2 per 100,000 women. One therapy for cancer treatment is chemotherapy. The side effects caused by chemotherapy are nausea and vomiting. In addition to drugs, complementary therapy given to chemotherapy patients is chamomile aromatherapy. This study aims to determine the effect of chamomile aromatherapy on reducing the scale of nausea after chemotherapy of cervical cancer patients in Dr. Moewardi Hospital. The type of research used is quasy experiment, using a research design non equivalent with the control group pretest and posttest design. The sample used was 30 patients with the criteria of patients who experienced Acute \& Delayed Nausea. Analyze data used Paired Samples Test and Independent T-Test. The results showed that the average scale of nausea before chamomile aromatherapy intervention was 15.40. And the average scale of nausea after intervention was 2.87 as evidenced by the value $\mathrm{p}=0.000(\mathrm{p}<0.05)$. The average value of the nausea after treatment scale in the control group was 7.33 , and the nausea scale average value in the intervention group was 2.87 . So that it can be concluded that there is an effect after being given chamomile aromatherapy to reduce the scale of nausea after chemotherapy with $\mathrm{p}=0.000$.
\end{abstract}

Copyright (c) 2019 Institute of Advanced Engineering and Science. All rights reserved.

\section{Corresponding Author:}

Ima Nurcahyanti,

Department of Midwifery,

Health Polytechnic of Semarang, Indonesia.

Email: nurcahyantiima@gmail.com

\section{INTRODUCTION}

The incidence of cervical cancer in the world is 17 per 100,000 women, while the mortality rate is 8.2 per 100,000 women [1]. While in Indonesia there are 274,000 deaths per year from cervical cancer [2]. Yogyakarta with a prevalence of $4.1 \%$. While the estimated absolute number of cervical cancer patients in Indonesia is highest in East Java Province with an estimated number of 21,313 people [3]. Report from the Police Obgyn Oncology at Dr. Moewardi Hospital disease which became the top 3 during the last is Cervical Cancer as many as 1,458 patients, malignant Neoplasm, Ovary, 933 patients and the number of endometritis as many as 301 patients. Therapy Cancer treatment is chemotherapy, radiotherapy, surgery or other methods. This chemotherapy treatment has a rest period. Throughout the phase of chemotherapy treatment until this rest period is referred to as 1 cycle. The level of chemotherapy for each patient is different depending on the severity and stage of cervical cancer [4].

According to the National Comprehensive Cancer Network (NCCN), the emetogenic activity of anticancer drugs can cause low nausea $(10-30 \%)$ at 5 -FU, and moderate nausea in severe (30->90\%) in the administration of Cisplatin. [4-5]. The requirement for chemotherapy is that the patient is in good physical condition, then performs various examinations of kidney function, liver function and EKG. In addition, the minimum examination standards indicate hemoglobin levels $>10 \mathrm{~g} \%$, leukocytes $>5000 / \mathrm{mm} 3$, and platelets $>150,000 / \mathrm{mm} 3$. 
Chemotherapy Induced Nausea and Vomitting (CINV) is a side effect of chemotherapy which is a big problem. CINV is divided into anticipation (which occurs before treatment is carried out), acute (during the first 24 hours after treatment) and delayed (after the first 24 hours after treatment and up to 5-8 days after treatment) [6]. Research conducted by Netty said that of the 30 patients given pharamological antiemetics the results were $50 \%$ of patients still experiencing nausea.

Vomiting is a reflex triggered by toxic substances, such as chemotherapeutic agents, causing cell damage in the stomach and small intestine. Broadly, these agents are felt in the small gastric or bowl mucosa and cause afferent vagal stimulation that interacts with the hind brain of the central nervous system (CNS), resulting in efferent vaginal action which ultimately leads to an emetic response [7].

Chemotherapy can cause nausea and vomiting through several varied mechanisms and a complex series. First, the vomiting center can occur indirectly by certain stimuli that can activate the Chemoreseptor Trigger Zone (CTZ) in the medulla, the role of CTZ as the chemosensor, this area is rich in various neurotrasmiter receptors such as histamine, serotonin, dopamine, opiate, neurokinin and benzodiazepines, whereas chemotherapy agents cause the process of vomiting through one of these receptors. Second, chemotherapy can cause interference with the gastrointestinal mucosa and cause the release of neurotrasmitters including 5HT3 (5 hydroxytriptamine). This causes nausea vomiting through a peripheral pathway mediated by the vagus nerve. Third, this symptom is caused by neurohormonal influences through the disruption of arginine vasopressin and prostaglandin. Fourth, nausea and vomiting are mediated by anxiety which affects the central nervous system including the vomiting center.

One of the midwives' actions is to provide a sense of comfort due to the side effects of chemotherapy, the action taken in the form of complementary therapy. Aromatherapy as part of complementary therapy can be used to improve the quality of life for cancer patients. Complementary therapies given to chemotherapy patients include aromatherapy. The most commonly recommended aromatherapy is cinnamon, chamomile, peppermint, fennel and rosewood.

Chamomile is known to be used in various forms of preparation. Dry powder from chamomile flowers is recommended and used by many people for traditional health problems [8]. The medicinal ingredients are usually extracted from chamomile dried flowers using water, ethanol or methanol as solvents and suitable extracts are known as extracts of water, ethanol (alcohol) and/or methanol. The optimal chamomile extract contains around 50 percent alcohol. Normal standardized extract contains $1.2 \%$ apigenin which is one of the most effective bioactive agents [9].

Apigenin and luteolin flavonoids have anti-inflammatory, carminative, and antispasmodic properties. Apigenin binds to GABA receptors and has a mild sedative effect. Coumarin umbelliferone is reported to be antispasmodic, antibacterial and antifungal. In herbal ingredients contain anti-spasmodic and improve the digestive system. Several studies have shown that $20 \%$ of the effects of nausea can be handled properly with non-pharmacological interventions, so that treatment of nausea using herbal interventions is recommended [9].

The use of essential oils inhaled is the most effective method, very practical and has the effect that can be directly felt compared to other techniques, this inhalation technique is easier to enter into the body without going through the absorption of cell membranes, steam molecules will directly regarding life receptors in the nasal cavity and directly connected to the olfactory nerve [10]. The scale of Index Nausea and Vomitting Retching was first published by Dr. Roxanne.W. McDaniel, PhD and Rhodes. V.A in 1999 to measure nausea and vomiting. And has been tested for validity and reliability [11]. The purpose of this study was to determine the effect of chamomile aromatherapy on reducing the scale of nausea after chemotherapy for cervical cancer, and to see the difference in the scale of nausea from the two groups.

\section{RESEARCH METHOD}

This type of research uses quasy experiment, with research design non equivalent with the control group pretest and posttest design [12]. In the design of this study, researchers used a control group as a comparison. The administration of chamomile aromatherapy was given to the intervention group, while in the control group respondents only took the antiemetic given from a doctor's prescription.

The population of this study was all cervical cancer patients who underwent chemotherapy. The sample used was 30 patients [13]. The sampling technique used purposive sampling with inclusion criteria being cervical cancer patients to stage III and who experienced Acute \& Delayed Nausea. Sample selection is done by finding patients with diagnosed cervical cancer and then adjusted to the late inclusion criteria determined. This research was carried out in the 7th Flamboyan Room in the gynecological chemotherapy Dr. Moewardi for 8-18 April 2019.

Data collection is done by interviewing using a questionnaire. Patients were interviewed three times. First, when making informed consent, the second at the pretest interview and third at the post test. 
Interviews at the pretest and posttest were conducted by telephone and assisted by the family. The research instrument uses the Index Nausea and Vomitting Retching (INVR) scale which has been standardized with 8 question points [14]. Values for each question from 0 as the smallest scale, to 4 as the largest scale. All points are summed to the following: 0 (No Nausea), 1-8 (Mild Nausea), 9-16 (Moderate Nausea), 17-24 (Severe Nausea), 25-32 (Great Nausea) [11].

Univariate analysis is used to describe the characteristics of respondents. In this study the variables studied were the age of the respondent, the frequency of chemotherapy, the history of the action ever taken, the results of the nausea scale before and after treatment in the intervention group and the control group. Univariate results are presented in the form of frequency distribution, percentage, mean, minimum-maximum value, and standard deviation.

Bivariate analysis in this study was to explain the effect of chamomile aromatherapy on the reduction of the scale of nausea after chemotherapy for cervical cancer and analyze the differences in the results of the nausea scale in the two groups. From the results of the normality test, it was found that the results were normal, so the test of the influence and difference using the Paired Samples Test and Independent T-Test. This research has passed the test of the ethical clearance committee of Sultan Agung University with letter number 092/A.1/FIK-SA/III/2019.

\section{RESULTS AND DISCUSSIONS}

\subsection{Overview of the research place}

This research was conducted in the Flamboyant Room 7 Dr. Moewardi Surakarta. This room is a chemotherapy ward specialized in surgical oncology and gynecological oncology. There is a hospital regulation that for obstetric oncology patients, every time they will undergo chemotherapy they must be hospitalized, one of them is cervical cancer. Patients are allowed to go home after a day after twelve or more hours. The chemotherapy drug used is a type of Cisplatin. Then the nausea medication prescribed after chemotherapy is Ondansentron tablets $4 \mathrm{mg}$ doses 3 times a day.

\subsection{Characteristics of respondents by age, frequency of chemotherapy and history of actions that patients have serviks cancer Dr. Moewardi Hospital}

The results of the description of frequency distribution show as shown in Table 1 that of the 15 respondents in the intervention group, they had an average age of 55 with a minimum age of 34 years and a maximum of 70 years. In the control group had an average age range of 57 years with the lowest age of 45 years and a maximum of 73 years. This can occur because of the long process of cancer cell degeneration that occurs in cancer patients. The degeneration process of cancer cells that takes a long time is accompanied by the body's resistance which decreases with age, making cancer cells more easily spread and only realized at the age above 30 years, so most cases already need to require chemotherapy [15-16].

Table 1. Overview of respondents in the control \& intervention group

\begin{tabular}{|c|c|c|c|c|}
\hline \multirow[b]{2}{*}{ Characteristics } & \multicolumn{2}{|c|}{ Intervention } & \multicolumn{2}{|r|}{ Control } \\
\hline & $\mathrm{F}(\%)$ & Mean (min-max) & $\mathrm{F}(\%)$ & Mean (min-max) \\
\hline Age & & $55(34-70)$ & & $57(45-73)$ \\
\hline Frequency of Chemotherapy & & $4.47(1-13)$ & & $4.20(1-12)$ \\
\hline \multicolumn{5}{|c|}{ History of Action } \\
\hline Radiation & $3(20)$ & & $7(46.7)$ & \\
\hline Operation & $12(80)$ & & $8(53.3)$ & \\
\hline Total & 15 & & 15 & \\
\hline
\end{tabular}

The results show that more than $60 \%$ of respondents had undergone surgery while others had done radiation up to tens of times. This is called the type of adjuvant chemotherapy. Chemotherapy is given after surgery. Its function is to kill the remaining cancer cells that have metastatic results and have a higher sensitivity to chemotherapy. In accordance with the existing theory that this therapy is expected to increase effectiveness, so that resistance is reduced and the chances of recovery are getting bigger. The results of the study also found that 14 respondents had undergone chemotherapy less than 3 times the most, then 13 respondents had undergone chemotherapy ranging from 4 to 9 times. This is in line with the literature that chemotherapy can be done after radiotherapy, or concurrently with radiotherapy called chemoradiotherapy, because chemotherapy makes radiation therapy work faster to improve [17-20]. 


\subsection{Frequency distribution of pre and post nausea scale based on control group respondents and interventions in cervical cancer patients}

The results of univariate analysis on the scale of nausea showed the number of respondents in the control group before being given antiemetics who had severe nausea as much as $59.8 \%$, and after being given antiemetics the number of respondents who had mild nausea was 53.3\%. In the intervention group, the majority of respondents had moderate nausea before being given aromatherapy as much as $59.8 \%$. After being given an chamomile aromatherapy intervention, most respondents felt mild nausea as much as $53.3 \%$. From the results of the study, the prevalence of respondents' nausea scale pretest in the intervention group was $59.8 \%$ experiencing moderate nausea, and $26.8 \%$ experiencing severe nausea. The post-test results of the nausea scale of respondents in the intervention group decreased to mild nausea by $73.3 \%$ and the rest felt mild nausea as much as $26.7 \%$, as shown in Table 2 .

Table 2. Distribution of pre and post nausea measurement based on control and intervention group respondents in cervical cancer patients

\begin{tabular}{cccccc}
\hline \multirow{2}{*}{ Characteristic Control } & \multicolumn{2}{c}{ Pre test } & \multicolumn{2}{c}{ Post test } \\
& f & $\%$ & f & $\%$ \\
\hline No Nausea (0) & - & - & 2 & 13.3 \\
Mild Nausea (1-8) & 1 & 6.7 & 8 & 53.3 \\
Moderate Nausea (9-16) & 4 & & 26.8 & 3 & 20 \\
Severe Nausea (17-24) & 9 & & 59.8 & 2 & 13.4 \\
Great Nausea (25-32) & 1 & & 6.7 & - & - \\
\hline Intervention & \multicolumn{4}{c}{ Pretest } & \multicolumn{2}{c}{ Posttest } \\
& \multicolumn{1}{c}{ f } & $\%$ & f & $\%$ \\
\hline No Nausea (0) & & - & - & 4 & 26.7 \\
Mild Nausea (1-8) & & 1 & 6.7 & 11 & 73.3 \\
Moderate Nausea (9-16) & 9 & 59.8 & - & - \\
Severe Nausea (17-24) & 4 & 26.8 & - & - \\
Great Nausea (25-32) & 1 & 6.7 & - & - \\
\hline
\end{tabular}

Meanwhile, the prevalence of nausea scale pretest in the control group was fairly evenly distributed, namely with the most severe nausea feeling 59\%, then 4 respondents felt moderate nausea, 1 respondent felt mild nausea and 1 respondent felt great nausea. In the post test results the nausea of the control group respondents had a less significant decrease, namely 8 respondents $(53.3 \%)$ most felt mild nausea, then there were 2 respondents no longer felt nauseous, but there were still 5 respondents who felt moderate to severe nausea $(33.4 \%)$.

Antiemetic drugs for prevention and treatment of post-chemotherapy vomiting are serotonin receptor antagonists (5-HT), including ondansetron. Ondansentron can be given in a single dose before chemotherapy or after chemotherapy. In accordance with the literature, this type of drug is effective for treating the levels of therapy that cause vomiting. The mechanism of action is thought to be carried out by antagonizing the 5-HT receptors present on the CTZ in the area of the brain postrema and possibly also the gastal gastrointestinal afferent. But the level of effectiveness also depends on the age of the patient because the work of the drug is also influenced by the body's metabolism of the patient [21-22].

Aromatherapy chamomile can be an option for increasing comfort in patients undergoing chemotherapy in overcoming the effects of chemotherapy. This is in line with the research conducted by Susanti who intervened Peppermint aromatherapy by inhalation to reduce the scale of nausea in chemotherapy patients at Panembahan Senopati General Hospital Bantul. So that the decrease in the nausea scale of the two groups has a different difference because the two treatments have different ways of working and are influenced by the body's endurance factors [23]. Several studies have shown that $20 \%$ of the effects of nausea can be handled well with non-pharmacological interventions, so that treatment of nausea using herbal interventions is recommended [24].

\subsection{The effect of chamomile aromatherapy on the reduction of the scale of post-chemotherapy nausea in cervical cancer patients in Dr. Moewardi Hospital}

From the results of the different test paired samples test as shown in Table 3, it can be seen the $\mathrm{p}$ value $=0.000(\mathrm{p}<0.05)$. This shows that there is a significant difference in the reduction of the nausea scale after chemotherapy before and after chamomile aromatherapy, so it can be concluded that the inhalation of aromatherapy chamomile effectively reduces the scale of nausea after chemotherapy in cervical cancer patients. From the results of nausea scale measurements before and after being given aromatherapy, respondents had a significant reduction in nausea scale. The inhaled aroma is faster in neutralizing the feeling 
of wanting to nausea vomiting, so aromatherapy chamomile has an influence in reducing the scale of nausea after chemotherapy in cervical cancer patients.

Table 3. Difference between nausea post chemotherapy scale before and after given chamomile aromatherapy

\begin{tabular}{cccccc}
\hline \multicolumn{2}{c}{ Category } & N & Mean & Min-Max & Sig \\
\hline Nausea & Pretest & 15 & 15.40 & $5-26$ & \multirow{2}{*}{0.000} \\
Scale & Posttest & 15 & 2.87 & $0-7$ & \\
\hline
\end{tabular}

When inhaling aromatic molecules, they move to the top of the nose where molecules come into contact with special nerve cells called olfactory cells. These cells have small hair that recognizes certain scents through a 'lock and key' process. This means that each hair will only recognize a particular aroma. This process produces nerve impulses that lead to the limbic system, the part of the brain that has the most influence on survival, instincts and emotions. According to scientists, nerve signal activity that passes through this area can cause mood changes by changing brain chemistry.

The results of the same study conducted by Susanti also showed a significant effect on the decrease in the scale of nausea between before and after peppermint aromatherapy administration in chemotherapy patients. The results of another study by Santi also showed the effect of blended peppermint aromatherapy and ginger oil on nausea in pregnant women [23]. Aromatherapy which is used by inhalation of its aroma is an effective method compared to other techniques because it can directly feel its properties through the olfactory nerve [25-26].

\subsection{The difference between giving chamomile aromatherapy to the intervention group and anti emetic giving in control groups against the reduction of post-chemotherapy nausea among cervical cancer patient}

In the Table 4 shows the results of the Independent T-test different test obtained $\mathrm{p}$ value $=0.039$ $(p<0.05)$ in the analysis of differences in nausea scale after being given treatment in both groups. This shows that there is a significant difference in the post-nausea scale given treatment in the intervention group rather than the control group.

Table 4. Effects of chamomile aromatherapy on the intervention group and anti emetic in the control group against the reduction of post-chemotherapy nausea scale

\begin{tabular}{cccccc}
\hline Category & & $\mathrm{N}$ & Mean & Min-Max & Sig \\
\hline Nausea & Control & 15 & 7.33 & $0-23$ & \multirow{2}{*}{0.039} \\
Scale & Intervention & 15 & 2.87 & $0-7$ & \\
\hline
\end{tabular}

In terms of the chemotherapy drug used is the type of Cisplatin which is a type of Level 4 drug with the possibility of causing nausea and vomiting reaching $>90 \%$. The administration of anti-emetic drugs used is a type of serotonin antagonist (5-HT3) with a single dose. Anti emetics that enter the body reach the highest levels in blood plasma after 1-2 hours of administration [27]. So that even though the administration of the drug is in accordance with the indications and needs, nausea still cannot be fully resolved. The results of previous studies also showed that all anti-emetics were still not effective in relieving nausea and vomiting after chemotherapy [28].

Judging from the results of the study, the level of decline in the scale of nausea was influenced by endurance, appetite, companion actions taken as well as drugs consumed. In patients undergoing chemoradiotherapy, nausea will be felt greater than those who only undergo chemotherapy and surgery. Radiation rays carried out on the inside and outside of the organs cause excessive effects of nausea and vomiting. Chemotherapy also has the same side effects of nausea and vomiting as radiotherapy. So if the respondent goes through both actions, it is certain that the level of nausea will increase so that the intervention provided can be less effective in reducing nausea due to the overpowering side effects of the nausea.

Anti-emetic drugs work in the body's metabolism of cancer patients for four hours. Most respondents are women over 50 years of age, so the possibility of absorption of drug substances is less effective than aromatherapy therapy which is directly inhaled by sufferers. In addition, this is possible because of the influence of chamomile aromatherapy and respondents who can still take anti-emetics at 
home. So that therapy to reduce nausea is twice as effective as the control group that only relies on anti-emetics given by the hospital

\section{CONCLUSION}

There is a significant influence on the administration of chamomile aromatherapy to reduce the nausea scale of cervical cancer patients as evidenced by the value $p=0.000$. There are differences in the nausea scale of cervical cancer patients when given treatment in the control and intervention groups as evidenced by the value of $\mathrm{p}=0.039$.

\section{REFERENCES}

[1] Ferlay J, Soerjomataram I, Ervik M, Dikshit R, Eser S, Mathers C. GLOBOCAN Cancer Incidence and Mortality. IARC Cancer Base No 11 [Internet]. 2012;1.0:5. Available from: http://globocan.iarc.fr.

[2] KPKN. Guidelines to Cervical Cancer Clinical Services. National Cancer Management Committee. Jakarta: Ministry of Health Indonesia; 2015.

[3] Riskesdas. Basic Health Research. Heal Res Dev Agency Minist Heal Repub Indones. 2013;82.

[4] NCI. Chemoteraphy. In: National Cancer Institute [Internet]. USA: National Cancer Institute; 2015. Available from: https://www.cancer.gov/about-cancer/treatment/types/chemotherapy

[5] NCCN. Antiemesis Nausea Guidelines. Natl Compr Cancer Netw. 2004;92(3):382-3.

[6] Rebecca Clark-Snow MLA, Rittenberg CN. Chemotherapy-induced Nausea and Vomiting (CINV) and Adherence to Antiemetic Guidelines: Results of a Survey of Oncology Nurses. US Natl Libr Med Natl Institutes Heal [Internet]. 2017;26(2):557-64. Available from: https://www.ncbi.nlm.nih.gov/pmc/articles/PMC5752733/

[7] Gershon M. Review Article: Serotonin Receptors and Transporters Roles in Normal and Abnormal Gastrointestinal Motility. Vol. 20. 2004. p. 3-14.

[8] Gardiner P. Chamomile (Matricaria Recutita, Anthemis Nobilis ). Cent Holist Pediatr Educ Res. 1999;1-21.

[9] Srivastava JK, Shankar E, Gupta S. Chamomile: A Herbal Medicine of The Past With Bright Future. Mol Med Report HHS Author Manuscr. 2011;

[10] Enikmawati A. Effect of Ginger Aromatherapy on Nausea and Acute Vomiting Due to Chemotherapy in Patients with Breast Cancer at PKU Muhammadiyah Hospital Surakarta. J Stikes EUB. 2015; VII(02):115-30.

[11] Rhodes V., McDaniel R. The Index of Nausea, Vomiting, and Retching ( INVR ). Oncol Nurse Forum. 1999;26:889-94.

[12] Sugiyono. Management Research Methods. Jakarta: Alfabeta; 2018.

[13] Dahlan S. Sample Size. Jakarta: Salemba Empat; 2016.

[14] Choi B, Kim T-H, Noh G. The Reliability and Validity of the Rhodes Index of Nausea, Vomiting and Retching in Postoperative Nausea and Vomiting. Korean J Anesthesiol. 2007;(January).

[15] Lasut E, Rarung M, Suparman E. Characteristics of Cervical Cancer Patients in Prof. Dr. R. D. Kandou Hospital. J E-Clinic [Internet]. 2015;3(April). Available from: https://ejournal.unsrat.ac.id/

[16] Prawirohardjo S. Midwifery. Jakarta: PT Bina Pustaka Sarwono; 2007.

[17] Rasjidi I. Cervical Cancer Epidemiology. Indones J Cancer. 2009;3(3).

[18] Junedi S, Ashari RA, C FM, Wijayanti TR, Widayanti E, Wijayanti NLS, et al. Cervical Cancer. In: Cancer Chemoprevention Research Center [Internet]. Fakultas Farmasi UGM; 2006. Available from: http://ccrc.farmasi.ugm.ac.id/?page_id=893

[19] Cancer Council S. Chemotherapy for Cervical Cancer. Cancer Counc SA. 2013;

[20] Deborah, Harsono, Sasotya S, Amarullah M, Hidayat D. Bandung Controversies and Consesus in Obstetrics \& Gynecology. Bandung: Sagung Seto; 2013.

[21] M. Adi F. Management of Chemotherapy-Induced Nausea and Vomiting. In: Mirror of the World of Medicine. 2010.

[22] Puspita Dewi A. Evaluation of Antiemetic Use in the Treatment of Breast Cancer in Inpatients at Dr. Moewardi Hospital Surakarta. digilib.uns.ac.id. 2011;

[23] Susanti D. Effect of Peppermint Aromatherapy on Decreasing Nausea Scale in Chemotherapy Patients in Panembahan Senopati Hospital Bantul. Repos UMY. 2016;36-50.

[24] Mustian KM, Devine K, Ryan JL, Janelsins MC, Sprod LK, Peppone LJ, et al. Treatment for Nausea and Vomitting During Chemotherapy. US Oncol Hematol Author Manuscr. 2014;7(2):91-7.

[25] Rihiantoro T, Oktavia C, Udani G. Effect of Inhalation Peppermint Aromatherapy on Vomiting Nausea in Postoperative Patients with General Anesthesia. Nurs J (Manila). 2018;XIV(1).

[26] Intansari R. Effect of Peppermint Aromatherapy on the Reduction of Nausea in SMC Telogorejo Hospital. J ilmu Keperawatan dan Kebidanan. 2015;

[27] Dipiro JT. Nausea and Vomitting: Pharmacotherapy Handbook. United State: The McGraw-Hill Companies Inc; 2006. 258-265 p.

[28] Nasif H, Junaidi, Muchtar H. Antiemetic Effectiveness in Patients Using Post-Surgical Sitostatics in Various Types of Cancer in Dr. Achmad Mochtar Hospital Bukittinggi. J Pharm Sci Technol. 2011;16(2):121-7. 